\title{
Endometriosis: unusual cause of groin swelling
}

\author{
Simon Rajendran, ${ }^{1}$ Ata Khan $^{2}$ Deirdre 0'Hanlon, ${ }^{2}$ Micheál Murphy ${ }^{3}$ \\ ${ }^{1}$ Department of General Surgery, Royal College of Surgeons, Dublin, Ireland \\ ${ }^{2}$ Department of General Surgery, South Infirmary Victoria Hospital, Cork, Ireland \\ ${ }^{3}$ Department of Radiology, South Infirmary Victoria University Hospital, Cork, Ireland \\ Correspondence to Dr Simon Rajendran, simonrajendran@gmail.com
}

\section{DESCRIPTION}

A 36-year-old woman presented with crampy lower abdominal pain and a lump in her left groin. The lump present for 3 years and has slowly increased in size with occasional episodes of tenderness. Her medical history includes hysterectomy for fibroids. Examination revealed a $2 \times 2 \mathrm{~cm}$ groin swelling lateral and superior to the pubic tubercle. CT revealed a solid lump above the inguinal ligament (figure 1). Ultrasound (US) demonstrated a solid mass with heterogeneous echogenic appearance (figure 2). Biopsy of the lesion revealed endometrial tissue. She declined surgical excision and gynaecology follow-up was arranged.

Extrapelvic endometriosis is an uncommon disease entity. The gastrointestinal tract is the commonest site, while endometriosis presenting in the groin is rarely seen. The lump may be painful with cyclical exacerbation or painless with only catamenial symptoms. The lump may fluctuate in size with menstruation or exhibit haemorrhagic tendency. The pathogenesis of groin endometriosis is believed to be either secondary to local spread from retrograde menstruation, systemic spread (lymphatic or haematogenous) or coelomic metaplasia. Coelomic metaplasia is believed to be the cause in women who have underwent hysterectomy and are not taking hormone

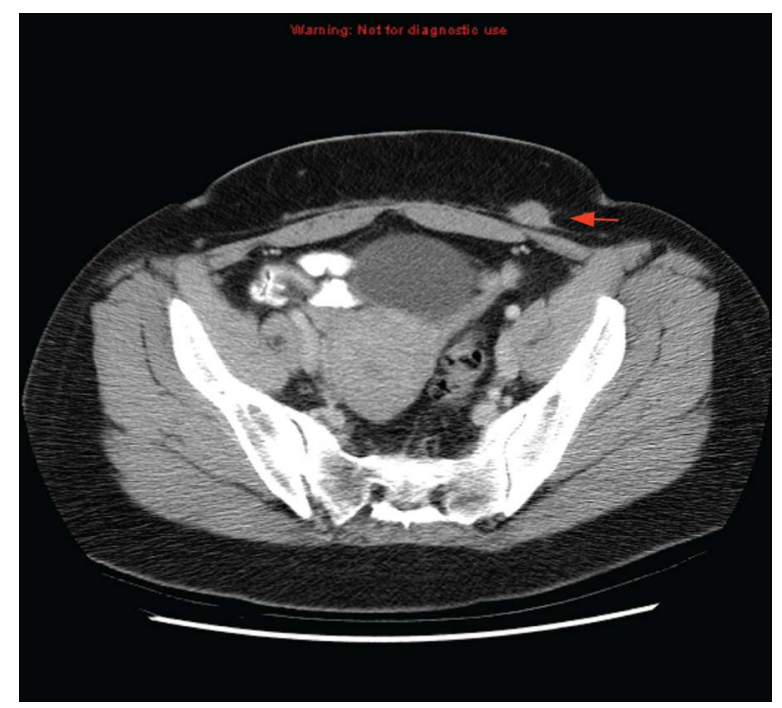

Figure 1 CT demonstrating mass adjacent to the rectus femoris muscle (red arrow).

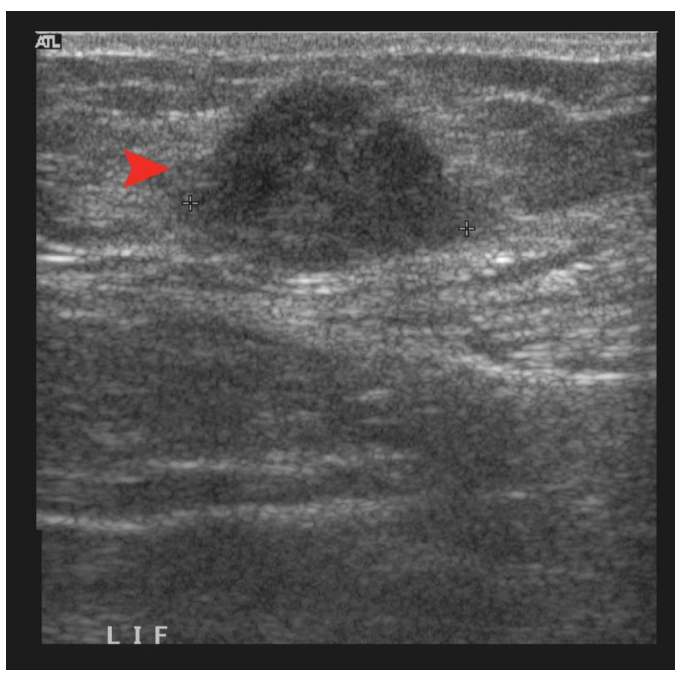

Figure 2 Ultrasound demonstrating a $2 \times 2 \mathrm{~cm}$ solid mass (red arrow) immediately anterior to the lateral margin of the rectus abdominis muscle with evidence of blood flow at the posterior aspect.

replacement therapy as in our case. ${ }^{12}$ US and CT are generally not diagnostic, however US features can be suggestive while CT will help define anatomy. ${ }^{1}$ Treatment options include expectant management, hormonal therapy or complete surgical excision with minimal spillage to avoid recurrence. ${ }^{3}$ Gynaecology referral is advised as pelvic endometriosis is frequently present concomitantly.

Competing interests None

Patient consent Obtained.

\section{REFERENCES}

1. Savelli L, Manuzzi L, Di Donato N, et al. Endometriosis of the abdominal wall: ultrasonographic and Doppler characteristics. Ultrasound Obstet Gynecol 2012;39:336-40.

2. Licheri S, Pisano G, Erdas E, et al. Endometriosis of the round ligament: description of a clinical case and review of the literature. Hernia 2005:9:294-7.

3. Candiani GB, Vercellini P, Fedele L, et al. Inguinal endometriosis: pathogenetic and clinical implications. Obstet Gynecol 1991;78:191-4. 


\section{BMJ Case Reports}

Copyright 2012 BMJ Publishing Group. All rights reserved. For permission to reuse any of this content visit http://group.bmj.com/group/rights-licensing/permissions.

BMJ Case Report Fellows may re-use this article for personal use and teaching without any further permission.

Please cite this article as follows (you will need to access the article online to obtain the date of publication).

Rajendran S, Khan A, O'Hanlon D, Murphy M. Endometriosis: unusual cause of groin swelling. BMJ Case Reports 2012;10.1136/bcr-2012-007526, Published XXX

Become a Fellow of BMJ Case Reports today and you can:

- Submit as many cases as you like

- Enjoy fast sympathetic peer review and rapid publication of accepted articles

- Access all the published articles

- Re-use any of the published material for personal use and teaching without further permission

For information on Institutional Fellowships contact consortiasales@bmjgroup.com

Visit casereports.bmj.com for more articles like this and to become a Fellow 